\author{
ELEK MÁRK
}

elekmark@yahoo.co.uk

hallgató (SZTE BTK)

\title{
Az ókori Skandinávia és kapcsolata a Római Birodalommal
}

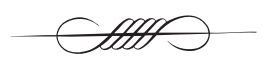

\section{- Ancient Scandinavian Peoples and their Connections to the Roman Empire -}

Abstract Scandinavia is well known for the Viking age period; numerous studies have been conducted regarding it. On the other hand, the Pre-Viking age status of the region is obscure as the Roman Empire did not stretch as far as Northern Europe, thus it had no direct contact with its people and as a consequence, only a limited number of written sources exist. My studyis aimed at introducing the Roman Iron Age period in Scandinavia from the first to the fifth century AD. With the help of ancient age and early medieval primary sources, archaeological artefacts and some linguistic research, the ancient age of Scandinavian history can be reconstructed. The centre of the study concentrates on the life, society andculture of Germanic people in Scandinavia, and their relation with the Roman Empire. My intention is to prove that although Northern Europe was far from the Mediterranean, Roman development and culture was able to reach that region through the trade and other forms of connections, so no area in Europe, not even Scandinavia, was able to remain isolated from the Empire.

Keywords Scandinavia, Roman Empire, roman-Scandinavian relations, society

DOI 10.14232/belv.2015.3.10

http://dx.doi.org/10.14232/belv.2015.3.10

Cikkre való hivatkozás / How to cite this article:

Elek Márk (2015): Az ókori Skandinávia és kapcsolata a Római Birodalommal. Belvedere Meridionale 27. évf. 3. sz. 100-109. pp

ISSN 1419-0222 (print) ISSN 2064-5929 (online, pdf)

(Creative Commons) Nevezd meg! - Így add tovább! 4.0 (CC BY-SA 4.0)

(Creative Commons) Attribution-ShareAlike 4.0 International (CC BY-SA 4.0) 


\section{Bevezetés}

Európa legészakibb lakott vidéke Skandinávia, melynekgazdag történelme elsősorban a viking kortól kezdve ismeretes. Ezzel számos kutatás és tanulmány foglalkozik, míg az ókori elözményekkel kapcsolatban csak kevés munka áll rendelkezésünkre, tanulmányomban ezért a régió ókori viszonyait kívánom középpontba helyezni.

A terület az ókorban meglehetősen ismeretlen volt, mivel a Római Birodalom legnagyobb kiterjedése, Traianus (Kr. u. 98-117) uralkodása idején sem voltak szomszédosak, ugyanis a Skandináviához legközelebbi római határ is Frízföld környékén húzódott.

A vizsgált terület alatt a Skandináv-félsziget déli része, és a Jylland-félsziget értendő. Időbeli kiterjedés tekintetében nagyjából az i.sz. első század közepétől az ötödik század elejéig tart a tárgyalandó időszak. A téma érdekessége abban rejlik, hogy Magyarországon szinte ismeretlen a régió történelme, sőt, a külföldi szakirodalom is marginálisan kezeli, mivel az ókorban csak csekély hatással bíró térség volt Skandinávia. Ugyanakkor nem volt teljes mértékben elszigetelve a Római Birodalomtól, ezt számos régészeti lelet ${ }^{1}$ is alátámasztja, ezek alapján lehet leginkább következtetni, mivel írásos forrás csak kevés van a korszakból.

Az egyidejű források a birodalomból származnak, de sokuk csak általánosságban foglalkozik a germán törzsekkel, és Skandinávia csak említés szintjén található meg bennük, azonban több szerzőnél is megjelenik a téma, bár ismereteik elég felszínesek. Ez főként annak köszönhető, hogy az antik szerzők nem első kézből származó információkat közölnek munkáikban, hanem azokat hallomás alapján írják le, esetleg más forrásokból. Leggyakrabban Skandinávia földrajzi adottságait jellemzik, - sokszor tévesen - valamint toposzokban

1 Ezek főleg római kézműves tárgyak, melyek a mai Közép-Svédország és Dél-Norvégia területéről kerültek elö. Pounds 2003. 96. említik a területet. A lakókról tudunk a legkevesebbet, hiszen Tacitus munkáján ${ }^{2}$ kívül a többi szerző az északi germán törzseket nem is említi, csak a többi népcsoporttal foglalkoznak. A vizsgált időszak után keletkezett kora középkori források is felhasználhatóak a témához, de ezek jelentősége csekélyebb, ezért csak viszonyításképpen alkalmazhatóak. A források időbeli kiterjedését figyelembe véve, azok széles skálán mozognak. Skandinávia legkorábbi említése ugyanis Plinius Naturalis Historia c. müvéhez ${ }^{3}$ köthető, míg a témára vonatkozó hozzáférhető források közül több is már az ókor után keletkezett.

A források, régészeti leletek és nyelvészeti ismeretek alapján következtetni lehet az ókori Skandinávia helyzetére. A feldolgozások több elméletet is felállítottak - fóleg a tárgyi leletekre alapozva - a Római Birodalommal folytatott kereskedelmi és politikai kapcsolatok létezésére. Ezek interpretálásával és a lakosság, terület, társadalom, valamint az ókori földrajzi elképzelések bemutatásával kívánok foglalkozni ebben a tanulmányban.

\section{Ókori elképzelések Skandináviáról}

Skandinávia elszigeteltségét mutatja, hogy az ókori és kora középkori szerzők kevés információval rendelkeztek a területről, csak néhányuk foglalkozott a leírásával. Jó példa erre Jordanes munkája, ${ }^{4}$ melyben több fejezetben jellemzi az általa szigetnek feltételezett Skandináviát, melyet Skandza néven említ. Kiemeli különleges éghajlatát, a hűvösségét, valamint a szokatlan napjárást is. Ez a forrás foglalkozik bővebben a terület földrajzi adottságaival, ugyanakkor a szerző maga nem járt ott, ezért eléggé pontatlan a hatodik századi leírás, mégis jól jellemzi az általános adottságokat.

A sziget egyfajta toposz, már az ókori forrásokban is így jelenik meg Skandinávia.

\footnotetext{
2 Tacitus: De Origine et situ Germanorum. (Szabó Árpád fordításában)

3 Plin. Nat. Hist. IV. 27.

4 Jord. Getica I-IV. 9, 16-24.
} 
Sőt, még a kora középkori ismeretekben is ez az elképzelés maradt fenn, hiszen Paulus Diaconus is így gondolkozik a területről. ${ }^{5}$ További szerzőknél ${ }^{6}$ is megjelenik a terület földrajzi leírása, azonban egyikük sem megy részletekbe és nem sokban különböznek egymástól. Azonban a forrásokból az következik, hogy a terület alapvető jellemzői már ismeretesek voltak számukra.

\section{Skandinávia lakossága, népei}

Skandinávia ókori népességét germánok és lappok alkották. Mivel a lappok ${ }^{7}$ elszigeteltségben éltek, és a későbbi időszakban sem lett jelentős politikai és gazdasági szerepük, ezért csak az ottani germán lakosságot érdemes vizsgálat tárgyává tenni. Mivel a germánok kisebb eltérésekkel kulturálisan és vallásilag is egységes népet alkottak, ezért bizonyos jellemzőikre az írásos források is felhasználhatóak. A Skandináviában élők nyelve az északi germán volt, mely az ókor végén kezdett el különválni a többi germán nyelvtől, ${ }^{8}$ ezért a vizsgált időszakban az eltérés nem volt olyan mértékű, hogy túlzott nehézséget okozzon a Skandináviában élő népeknek egymás közötti, illetve a területhez közel eső germánok közötti kommunikációban. Egyes állítások szerint 450 előtt biztosan nem alakultak ki skandináv vonások a germán nyelvben, és 550-ig nem látszik a rúnafeliratokon változás, ugyanakkor ezzel szemben felvetődött, hogy már korábban is megváltozott a fonológiája, morfológiája és jelentéstartalma a feliratoknak, melynek egyik példája a 350-400 körül készült és Jyllandon talált Gallehus rúnafeliratos szarv, melyen specifikus skandináv nyelvi elemeket véltek

\footnotetext{
5 Paulus Hist. Lang. I. 1.

6 Például Ptolemaeus, Jordanes, Paulus Diaconus. Csak a középkorban keletkeztek részletes leírások: például Historia Norvegiae.

7 A lappok főként halászó, vadászó nomád nép, amely sokáig megőrizte kultúráját és szokásait. WIIK 2008. 168.

8 WIIK 2008. 195-196.
}

felfedezni. ${ }^{9}$ Ez sem jelenthetett túl nagy eltérést, ezért nyelvi hasonlóságról beszélhetünk. Ezen kívül további közös pontok is voltak a germánoknál. Közös eredettudattal rendelkeztek, melyet a föistenüktől, Odintól ${ }^{10}$ származtattak. E mellett politeisták és bár egyes területeken voltak eltérések, ${ }^{11}$ ezeknek a római források által is említett föbb isteneknek a tisztelete volt a meghatározó. A római szerzők leírásaikban megpróbáltak analógiát vonni a germán és a római istenek között. Tacitus, és Caesar is római istenekként azonosították ${ }^{12}$ a germán isteneket. Ez valószínűleg a kultúrák közötti hasonlóság keresése miatt alakult így, hiszen ez által jobban megérthették a tőlük különböző népeket. Tacitus említi ${ }^{13}$ a jóslás fontosságát, itt is párhuzam vonásával ábrázolja a germán hiedelmet, ugyanis amíg a rómaiak föleg madarak szokásai alapján, addig a germánok főként lovakkal, és csontokkal jósolnak. A germánok számára rendkívül fontosak voltak a hiedelmeik, a kereszténység sem jutott el hozzájuk az ókorban, az egyik első térítő, Anskar csak a 9. század második felében indult Skandináviába. ${ }^{14}$ A szokások, nyelv és kultúra hasonlósága miatt azonban elmondható, hogy az egyes népeket nehéz megkülönböztetni egymástól.

Ugyanakkor több germán nép is Skandináviából eredezteti magát, melyre sok esetben nincs egyértelmü bizonyíték. Mégis több szerzőnél is megjelenik, és egyfajta toposznak lehet tekinteni. Jordanes a gótokat, ${ }^{15}$ Paulus Diaconus pedig a langobardokat ${ }^{16}$ ere-

9 BARnes 2003.98-99.

10 A skandináv mitológia föistene, a délebbi germánok Wotannak is nevezték. BRøNDSTED 1983. 244-245.

11 Például a középkori Norvégiában Thor istent tisztelték a legjobban, Sawyer ezzel kapcsolatban felállított egy elméletet, miszerint ez is oka volt annak, hogy a Norvég Királyság sokkal nehezebben alakult ki, mint azok a királyságok, ahol Odiné volt a vezető szerep, mivel Odin kultusza jobban alátámasztotta az egyeduralmat, mint Thoré. SAWYer 1982. 131.

12 Tac. Germ. 9.; Caes. DBG 6. 21.

13 Tac. Germ. 10.

14 Sawyer 2010. 100-101.

15 Jord. Getica I. 9.

16 Paulus Hist. Lang. I. 1. 
dezteti innen például. Néhány nép esetében azonban feltételezhető a skandináv származás, melyet több forrás is megerösít. A Tacitusnál megjelenő suin nép az egyik ilyen. Leírása szerint erős flottával rendelkeztek és jó hajósok voltak, a királyuk korlátlan hatalommal rendelkezett, és a fegyvereiket nem tarthatták maguknál, nehogy garázdálkodni kezdjenek, mert a tenger egyébként is védelmet nyújtott számukra. ${ }^{17}$ A szerző megemlíti továbbá, hogy vitorlát nem használnak, és az evezők sem kötött helyen vannak, hogy könnyebben hajózhassanak a folyókon, a kikötés elösegítése végett pedig a hajó mindkét végén orr található. ${ }^{18}$ A suinok feltehetően a mai svédek elődei, de csak kis hányadát alkották az ókori Skandinávia lakosságának, valószínüleg egyfajta helyi hegemóniát alakíthattak ki a térségben. ${ }^{19}$

Valószínűleg a Jordanes által említett danusok, a mai dánok elödei élhettek a suinok szomszédságában, és a szerző szerint: „minden scandiai között a kimagasló névre vágytak magas termetük miatt" 20 Ök voltak azok, akik Jylland korábbi lakóit, egy másik skandináv eredetű népet, a herulokat kiüzték valamikor az 5. század elején. ${ }^{21}$ Róluk kiüzésüket követően vannak információink, több részre szakadtak, egy részük a mai Spanyolország és Franciaország területét fosztogatta, és gót szolgálatba állt, míg feltételezhető, hogy néhányuk a Duna környékéig is eljutott. ${ }^{22}$

Még egy nép van, amelyről több forrásból információval rendelkezünk, igaz csak későbbiek alapján. A jütök ugyanis feltehetően a Jylland-félsziget környékéről származhattak Bede Venerabilis leírása ${ }^{23}$ alapján, valamint

17 Tac. Germ. 44.

18 Érdekes hasonlóságokat lehet ez alapján felfedezni a későbbi viking hajókkal. Tac. Germ. 44.

19 A Mälar tó környékén. CoOK-ADCock-CHARLESWORTH 1954. 63.

20 Jord. Getica III. 23.

21 Halsall 2007.380-381.; Gwyn Jones ezt az eseményt a 3. századra teszi. JONES 2001. 29.

22 Halsall 2007. 381.; Jones 2001. 28-29.

23 Bede Hist. XV. megemlíti őket az Angolszász Krónika ${ }^{24}$ is, bár ennél több információt ezek alapján nem lehet kikövetkeztetni a jütök skandináviai tartózkodásáról. Felsorolás jelleggel még néhány skandináv nép megjelenik az ókori és kora középkori szerzőknél, de ezekről bővebb információ nem áll rendelkezésünkre.

\section{Társadalom}

A skandináv társadalom megértéséhez az írásos források nyújtanak segítséget, ugyanis az általános jellemzőket párhuzamba lehet állítani a délebbre élő germán népek szokásaival és berendezkedésével. Továbbá az újabb régészeti leletek alapján is érdekes következtetéseket lehet levonni a társadalomi viszonyokról. Ezek alapján a társadalom alapvetően két rétegre bontható. A szabadok, akik a germán hagyományoknak megfelelően nagy szabadságjogokkal rendelkeztek, különös tekintettel a népgyülés intézményére, és a királyi, törzsföi hatalom korlátozására. A másik csoport a szolgák rétege, akik alávetett szerepet töltöttek be, ugyanakkor másféleképpen, mint ahogyan például a rómaiaknál megfigyelhető. A skandináv törzsek a germán etnogenezisnek ${ }^{25}$ megfelelöen alakultak egyre szervezettebbé, ezzel a társadalom komplexitása is növekedett, így például vezetőréteg is kialakult.

Sokáig nem figyelhető meg a társadalom nagymértékű differenciálódása Skandináviában. A feltárások megvilágítják Jylland ${ }^{26}$ helyzetét az 5. század előtti időszakban. A mai Dánia területén talált legnagyobb falvak maximum 200 fós lakossággal rendelkeztek, és a földművelés volt a fö tevékenység a területen. Ez viszonylag stabil rendszer volt gazdaságilag és politikailag is, melyet alátámasztanak a házak maradványai és a sírok is. Nagyjából

24 Garmonsway 1978. 13.

25 Wenskus elméletének összefoglalását lásd: BoLLóK 2006. 268-269.; CHRISTIANSEN 2008. 112.

26 A Rómához legközelebb eső terület, jó természeti adottságokkal, ezért ezt kívánom bemutatni, azonban egyéb területeken is történtek feltárások. Norvégia esetében lásd: STYLEGAR 2013. 404-421. 
Kr. u. 200 után a falvak egyre tervezettebb benyomást keltenek, ami bizonyos társadalmi szervezőerő jelenlétét feltételezi. Ezek alapján feltételezhető, hogy a lakosság szabad birtokosokból, bérlőkből és földnélküliekből tevődött össze. ${ }^{27}$ Az uralkodói elit kialakulásának folyamata azonban tovább tartott: csak a római hatalom meggyengülésével párhuzamosan kezdett bizonyíthatóan jelentőséget és stabilitást kapni az 5. században, a régészeti leletek ennek megfelelően ekkorra már a szakrális funkcióikat is igazolják. ${ }^{28}$

Az általános germán jellemzők vonatkoznak a skandináv szabadokra is, ezért azokat figyelembe lehet venni. Ez alapján Tacitus munkáját lehet megvizsgálni a réteg felépítésével kapcsolatosan. A germán, így a skandináv szabadok is komoly jogokkal rendelkeztek az ókorban még csak formálódó uralkodói hatalommal szemben, melynek az egyik legföbb alapja a népgyülés intézménye volt. ${ }^{29} \mathrm{Ez}$ korlátozta ugyanis a törzsfök hatalmát, ugyanis Tacitus szerint a kisebb ügyekben a törzsfök tanácsáé volt a döntő szerep, de a nagyobb ügyeket a népnek kellett engedélyeznie. ${ }^{30}$ Rendszeresen ül össze a gyülés, és bírói szerepe is van. A vitás ügyeket a gyűlések alkalmával tárgyalták, ${ }^{31}$ így ez az intézmény láthatóan eléggé sokoldalú. A törzsfök egyébként is általában a legrátermettebb emberekből kerültek ki katonai érdemeik és bátorságuk alapján: „Királyaikat előkelő származásuk, vezéreiket vitézségük alapján választják". ${ }^{32}$ A vezetők gyűlése, a népgyülés és a királyi kíséret intézménye $^{33}$ a germánoknál már Caesar idején

27 MYhre 2003. 71.

28 Halsall 2007. 380.

29 Tacitus a népgyűlést és a királyi hatalmat jellemzi több fejezetben. Tac. Germ. 11-13.

30 Tac. Germ. 11.

31 Tac. Germ. 12.

32 Tac. Germ. 7.

33 A középkorban is fennmaradtak a tartományi gyülések, szerepükről az első írásos források 13. századiak. A királyi hatalom nagysága attól függött, hogy a király mennyire tudta befolyása alá vonni a gyüléseket, megvoltak, de hatáskörük megváltozott, már nem csak háború idején kaptak szerepet. ${ }^{34}$ Ugyanakkor a skandináv helyzetről pontos információ nem áll rendelkezésre a források alapján, vélhetően ott is megkezdődtek ezek a változások a Kr. u. 2. század folyamán, vagyis a törzsfők egyre nagyobb hatalomra tettek szert és a törzsek egyre szervezettebbek lettek, ami a kereskedelem fellendülésének is köszönhetö. ${ }^{35}$ Elmondható azonban az előzőeknek megfelelően, hogy ez elhúzódó folyamat volt, és tovább tartott, mint a délebbi germánok esetében.

A szolgák rétege feltételezhetően kiterjedt volt az ókorban, azonban ekkor még nem állt rendelkezésre összeírás. Csak a 14. századi péterfillérekből lehet következtetni az akkori állapotokra, ami szerint a társadalom nagyjából 20\%-át tehették ki a rabszolgák a középkorban. ${ }^{36} \mathrm{~A}$ viking kori nagymértékủ rabszolga beáramlás előtt azonban valószínűleg jóval kisebb, de még mindig jelentős arányban voltak jelen. Helyzetüket vizsgálva elmondható, hogy alapvetően más, mint a római rabszolgáké, mivel saját tanyájuk volt, és csak beszolgáltatási kötelezettségük volt, ellentétben a római viszonyokkal, ahol Tacitus szerint a feladataik meg vannak szabva, és emiatt sokkal függőbb viszonyban vannak. ${ }^{37}$ A germán szolgarétegnél tehát kisebb mértékű alávetettség és személyi függőség feltételezhetö ${ }^{38}$, ezért a szolgaság a germánoknál ezek alapján jobb helyzetben lehetett, mint Európa más térségeiben. A skandinávok, és a délebbre élő germánok között valószínűleg e tekintetben nem volt nagy különbség. Sőt, a szolgák és a szabadok közti viszony is engedé-

amit általában a királyi kísérettel, ahogy a középkorban nevezik a hirddel ért el. SAWYER 2010. 80-84.

34 Tacitus idejére már békeidőben is volt szerepe. SzÉKeLY 2011. 26-28.; Caes. DBG 6.23.

35 Anderson 1999. 17-18.

36 Moberg 1984. 29-30.

37 Tac. Germ. 25.

38 Csak feltételezés van a rabszolgák pontos helyzetével kapcsolatban. Moberg 1984. 28-29. 


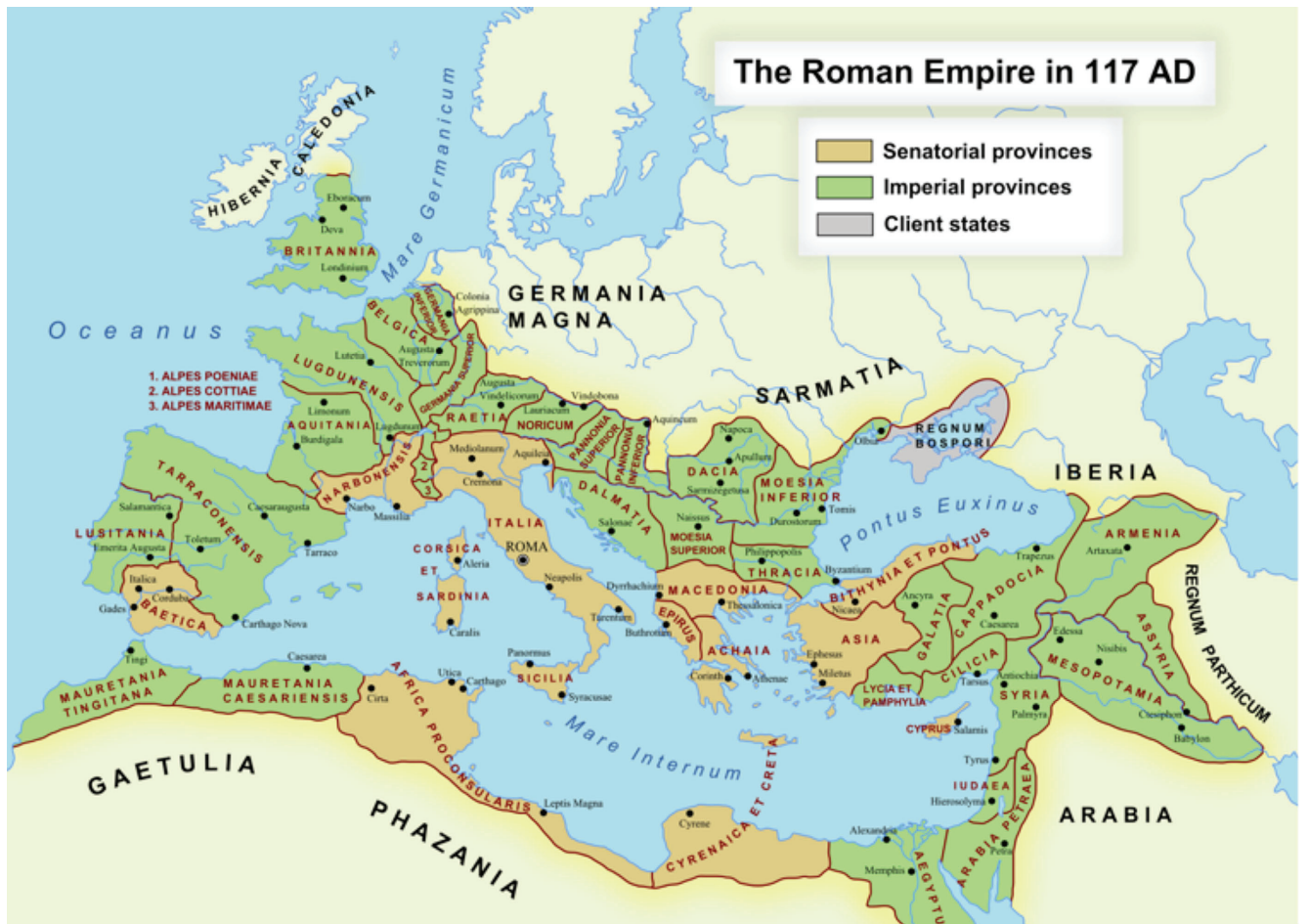

1. ÁBRA * A Római Birodalom a Kr. u. 2. században. Elérhető: http://www.ancient.eu/image/266/ Hozzáférés: 2015.08.21. 11:40.

keny volt, hiszen például ha egy szolga nőnek szabadtól született gyereke, akkor azok nem voltak elidegeníthetőek a tulajdonostól, és a két réteg közötti ilyen jellegű kapcsolat már az ókorban is elterjedt volt. ${ }^{39}$

\section{Kereskedelmi kapcsolat Rómával}

Skandinávia távol helyezkedett el a Római Birodalomtól, ezért közvetlen kapcsolat nem volt a két terület között, de Észak-Európa nem volt teljesen elszigetelt a kontinens többi részétől, ezért közvetett módon kapcsolatba került a birodalommal. Az írásos források hiánya miatt nehéz rekonstruálni a viszonyt, azonban a régészeti leletek segítséget nyújtanak ehhez. Alapvetően a kereskedőknek volt köszönhető a kapcsolat, a kevés rendelkezésre álló írásos forrás pedig többségében az ő el-

\footnotetext{
39 Moberg 1984. 26.
}

mondásaik alapján keletkezett. A kereskedők az eszközök cseréjében és a technológia fejlesztésében fontos szerepet játszottak. Skandinávia déli részének ${ }^{40}$ volt elsősorban szerepe a kereskedelemben, ugyanis a Római Birodalom és Baltikum $^{41}$ közti kereskedelmi útvonalak itt értek össze, erről több régészeti lelet is rendelkezésünkre áll. Közvetlen kereskedelme a birodalomnak azonban nem volt Skandináviával, a frízföldi és britanniai kereskedőkkel álltak kapcsolatban. ${ }^{42}$

Földrajzi elhelyezkedése miatt a legkorábbi római leleteket (elsősorban edényeket) Dániában találták, és mennyiségüket tekintve is itt van a legtöbb. A Kr. u. 40-es évektől talál-

40 Ami a mai Oslo-Stockholm vonallal nagyjából megegyező limes norrlandicus vonalától délre fekvő területek. Erről bővebb információ: WIIK 2008. 166-173.

41 Tacitus a balti népek leírásakor, akikkel esetleg a skandinávok is kapcsolatban állhattak, említi hogy legfőbb exportcikkük a borostyán. Tac. Germ. 45.

42 Anderson 1999. 15-16. 
ható itt lelet, elsősorban a Jylland-félszigeten és a legjelentősebb dán szigeteken (Fyn, Lolland, Møn, Sjælland). Eloszlásuk korszakonként és területenként változatos, de számos tárgyi emlék maradt fenn erről a területről. ${ }^{43} \mathrm{~A}$ Svédországban és Norvégiában talált leletek mennyisége és keletkezésük ideje hasonló mintát mutat, de ebben a térségben a legkorábbi leletek jóval későbbiek, mint Dániában. A Skandináv-félszigetre a Kr. u. 70-es évektől jellemzőek római tárgyi emlékek, de csak nagyon kis mennyiségben, továbbá a Kr. u. 160-210 közötti időszak leleteinek a datálása is nehéz, ezért nem lehet pontosan megállapítani a korszakból származó tárgyi emlékek pontos mennyiségét sem, fölrajzi elhelyezkedésük azonban megállapítható: Norvégiában az Østfjord térségben, Svédországban pedig elsősorban Gotland, Scania, Västergötland és Öland területén találhatóak. ${ }^{44}$ A kereskedelem egészen a Római Birodalom visszaszorulásáig, vagyis az 5. század elejéig fennmaradt. ${ }^{45}$ Ekkor ugyanis az utolsó római légiók is kivonultak a két terület közötti kapcsolatot biztosító Britanniából, és ezzel párhuzamosan az ottani hatalom is felaprózódott. ${ }^{46} \mathrm{~A}$ Britanniával való kereskedelmi kapcsolat a Jylland-félszigettel tárgyi emlékek alapján egészen a 6 . századig fennmaradt, ${ }^{47}$ de a rómaiak kiszorulásával a birodalommal való kapcsolat megszünt. Ezután Róma túlzottan le volt kötve a germán támadásokkal, ${ }^{48}$ így a közvetítő kereskedelmet biztosító területekkel megszakadt a kapcsolat, ezért Skandinávia elszigetelődött. \{1. ÁBRA $\}$

Maguk a leletek többféle tárgyi emléket jelentenek. A legjelentősebbek közé a sírokból előkerült fegyverek, edények és egyéb ajándéktárgyak tartoznak, melyek kapcso-

\footnotetext{
43 GRANe 2007. 152-153.

44 Grane 2007. 152-154.

45 SzÁnTó 1997. 10.

46 Collins 2007. 132.

47 Főleg Kent területére érkeztek dél-skandináv tárgyak. YORKE 1992. 26.

48 BLOCKLEY 2007. 118-125.
}

latba hozhatóak a rómaiakkal. ${ }^{49}$ További tárgyi emlékek közül megemlítendőek a római pénzérmék, melyekből meglehetősen sok, nagyjából 11000 darab maradt fenn. A legelső első századi, de még a 3. századból is előkerültek többségében ezüst, kisebb mennyiségben arany érmék. ${ }^{50}$ Mennyiségük és eloszlásuk megmutatja a Skandináviára gyakorolt római hatás területi kiterjedtségét. ${ }^{51}$ Végül az egyéb tárgyi leletek, például a kézmüves termékek, mint az üvegtárgyak, melyeket a skandinávok technológia hiányában nem tudtak elkészíteni, csak importálták a Római Birodalomból, s ez szintén a kereskedelem meglétére utal. A rómaiak érdekében állt a kereskedelmi kapcsolatok fenntartása Skandináviával: nyersanyagokat importáltak, germán kereskedőket alkalmaztak, a törzsfök fiait taníttatták azért, hogy előmozdítsák a két terület közötti kapcsolatot, amivel akár szövetséget köthettek, melyhez politikai érdekeik is füződhettek. ${ }^{52}$

\section{A római-skandináv kapcsolatok egyéb aspektusai}

Az esetleges szövetségeket figyelembe véve érdekes felvetés a római és skandináv katonai kapcsolatok kérdése. Bár az írásos forrásokból nem lehet erre következtetni, a régészeti leletek felvetik az ilyen jellegü kapcsolatok létezésének lehetőségét is. Ez a kapcsolat ugyanis abbólállt volna, hogy a skandináv törzsek, illetve harcosok katonai szövetséget kötöttek az északabbra fekvő római provinciákkal. Ezt a felvetést Thomas Grane tíz síremlékre alapozza, melyekből arra következtet, hogy az első három évszázadban katonai és politikai kapcsolat lehetett a két terület között. Ezek a feltárások gazdag germánok sírjait tartalmazzák, és több római tárgyat is találtak bennük. Arany, ezüst tárgyakat, fibulákat, kardokat, és egyéb értékes római eredetű tárgyakat, amik jelenlétéből

\footnotetext{
49 Grane 2007. 188-191.

50 ANDERSON 1999. 17.

51 Grane 2007. 164-166.

52 Myhre 2003. 69.
} 
arra a következtetésre jut a szerző, hogy ajándékként ${ }^{53}$ kerülhettek Skandináviába, ami felveti a politikai kapcsolatok lehetőségét. ${ }^{54}$

A római eredetű fegyverek, páncélok és pajzsok szintén ezt a feltételezést támasztják alá. Ezek nem feltétlenül gazdagok sírjaiból kerültek elő (mint például a 2. századi Brokær lelet), hanem valószínü, hogy a Dél-Skandináviához közeli vidéken a római katonák kereskedelmi megállapodásokat is kötöttek helyi lakosokkal. Ebből Grane azt a következtetést vonja le, ${ }^{55}$ hogy a kis távolság miatt ilyenek Skandináviában is előfordulhattak, bár ez utóbbi állításra véleményem szerint nincs elég bizonyíték. A szerző ezekből az adatokból fenntartja a lehetőségét, hogy egyes skandináv törzsek politikai szövetséget kötöttek a rómaiakkal, vagyis foederati lehettek. ${ }^{56}$

Feltételezhető továbbá a skandináv zsoldosok $^{57}$ jelenléte a limesnél. Ezt a feltételezést germán eredetű edényekre alapozva magyarázza Grane, ugyanakkor elismeri, hogy nagyon keveset találtak ahhoz, hogy megalapozott teória legyen. Mindenesetre elképzelhető, hogy néhány harcos (föleg Sjællandból) római szolgálatba állt a markomann háborúk után, majd ott maradtak római területen. Erre az általuk használt edényekböl lehet következtetni. Ha ez a feltevés igaznak is bizonyul, valószínüleg nem nagyszámú harcosról beszélhetünk. ${ }^{58}$

Ezeken a kapcsolódási pontokon kívül

53 Az ajándékozásnak fontos szerepe volt a germánok és rómaiak közti kapcsolatban is. Az ajándéktárgyak főleg luxustermékek voltak, és a törzsfők kapták őket általában. A jelenségről bővebben: Székely 2011. 2931.

54 Grane 2007. 167-171.; A politikai kapcsolatok lehetőségét Anderson is felveti. ANDERson 1999. 21-22.

55 Grane 2007. 171-173.

56 Grane 2007. 167-168.

57 A tárgyi emlékek alapján a skandináv hadszervezet rekonstruálására is sor került. E szerint nagymértékủ római hatás érezhető rajta, Jylland területén a feltételezések szerint akár 500-1000 fös seregek is összegyülhettek lovasokkal, ijászokkal és vezetőkkel. MyHre 2003. 74-75.

58 Grane 2007. 183-188. érdekes kérdés még a kulturális kapcsolatok mértéke, amit a germán rúnaírás változásán keresztül is vizsgálat alá lehet venni. Ha a birodalom nem is, de a római kultúra hatása elérte Skandináviát. ${ }^{59}$ A 4-6. század folyamán Közép-Európában, Britanniában és Skandináviában az idősebb, 24 betűből álló futharkot ${ }^{60}$ használták. Ezt Közép-Európában fokozatosan felváltotta a római abc. Skandináviában azonban csak a 9. század folyamán váltott át a 24 betűs futhark 16 betűssé, ami valószínüleg a kereszténység terjedésének a következménye volt, vagyis a betűket latin szöveg írására is elkezdték alkalmazni, esetleg az ekkoriban végbemenő nyelvi változások tették szükségessé az írás megváltoztatását. A kulturális hatások tehát igaz, hogy lassabban érték el Észak-Európát, mint a kontinens többi részét, de mégis elérték. ${ }^{61}$

A római-skandináv kapcsolatok többsége a források hiánya miatt nem bizonyítható megfelelően. Ami bizonyos, hogy római tárgyak eljutottak Skandináviába, de a térség koránt sem állt olyan mértékü római hatás alatt, mint a birodalomhoz közelebb eső vidékek. A germán törzsek közül az északiakat érte a legkisebb római hatás. Ugyanakkor teljes mértékben nem szigetelödött el Európa e távoli szeglete, a megtalált régészeti leletek ezt bizonyítják. Véleményem szerint számottevő hatást ${ }^{62}$ nem gyakorolt a Római Birodalom Skandináviára, de kétségtelenül hatással volt rá, mivel a birodalomtól szinte lehetetlen lett volna teljesen elszigetelödni.

59 Brøndsted szerint a legvalószínűbb, hogy a rúnaírást a 2. században közvetlen vagy közvetett római hatásra kezdték el alkalmazni a germánok. BRøNDSTED 1983. 175. Ennek az elméletnek mond részben ellent az alább kifejtett rész.

60 A germánok által Európa-szerte használt ábécé, rúnaírás. Nevét az első hat betüjéről kapta. JónAsson 2003. 9.

61 JónAsson 2003. 55-56.

62 Anderson azon az állásponton van, hogy az ókori Skandinávia nem esett kívül a római befolyás övezetén, ha közvetlen katonai fenyegetés nem is érte. ANDERSON 1999. 15. 


\section{Összegzés}

Összegzésképpen elmondható, hogy Skandinávia az ókorban marginális térség volt, ezért kevés forrás van a területtel kapcsolatban. Elsősorban a régészeti leletek alapján, valamint a nyelvészet segítségével azonban valamelyest rekonstruálható a lakosság és a társadalom, mely nagy hasonlatosságot mutat a délebbi germánokkal. A távoli fekvése ellenére azonban nem maradt teljesen elszigetelve Európa többi részétől. Ugyanis közvetett kereskedelmet folytatott a Római Birodalommal, melyet a tárgyi emlékek is alátámasztanak. Ugyancsak utalnak a két terület közötti kapcsolat egyéb aspektusaira is: politikai és katonai szövetség lehetősége is felvetődik mindezek alapján. Azt azonban el kell ismerni, hogy a kisszámú lakosság és nyersanyagokban szegény terület Rómára való hatása nem volt túl jelentős. Ennek ellenére az az érdekes megállapítás vonható le, hogy Európában még egy ilyen távoli és eldugott vidék sem maradhatott az ókorban teljesen elszigetelt, és bár a birodalom nem ért el Skandináviába, mégis hatással volt rá.

\section{FELHASZNÁLT IRODALOM}

Források

BEDE VENERABILIS: Ecclestical History of the English Nation. Book I. http://www.fordham.edu/halsall/ basis/bede-book1.asp Hozzáférés: 2013.10.06.

Bostock, J. - Riley, H. T. (transl.) (1855): The Natural History of Pliny. London.

Caesar, Julius (1994): A gall háború. Ford, jav.: Szepessy Tibor. Szeged.

Garmonsway, G. N. (translated) (1978): The AngloSaxon Chronicle. New York.

Iordanes (2004): Getica. A gótok eredete és tettei. Budapest.

Paulus Diaconus (2012): A langobardok története. Gombos F. Albin ford. felhasználásával közread. Galamb György. Budapest.

SzABÓ ÁRPÁD (ford.) (1961): A germánok eredete, földje, szokásai és népei. In Borzsák István (válogatta): Tacitus. Budapest.

\section{Feldolgozások}

Anderson, Carl Edlund (1999): Formation and Resolution of Ideological Contrast int he Early History of Scandinavia. St John's Collage. (A Dissertation submitted for the degree of Doctor of Philosophy)

BARnes, Michael (2003): Languages and ethnic groups. In.: Knut Helle (ed.): The Cambridge History of Scandinavia. Vol I. Prehistory to 1520. Cambridge.

Blockley, R. C. (2007): The dinasty of Theodosius. In Averil, Cameron - Garnsey, Peter (ed.): The Cambridge Ancient History Vol. XIII. The Late Empire, A.D. 337-425. Cambridge.

Bollók ÁDÁM (2006): Új irány a koraközépkori etnogenezis-kutatásban? : Gillett, Andrew (szerk.): On Barbarian identity. Critical approaches to ethnicity in the Early Middle Ages. (Studies in the Early Middle Ages 4.) Turnhout, 2002. Korall 7. évf. 24-25 sz. 265-282.

Brogan, Olwen (1936): Trade between the Roman Empire and the Free Germans. The Journal of Roman Studies vo. 26. no. 2. 195-222.

Brøndsted, Johannes (1983): A vikingek. Budapest. Christiansen, Eric (2008): Vikingek. Debrecen.

Collins, Roger (2007): The western kingdoms. In Cameron, Avril - Ward-Perkins, Bryan - Whitby, Michael (ed.): The Cambridge Ancient History Vol. XIV. Late Antiquity: Empire and Successors, AD. 425-600. Cambridge.

Cook-AdCock-Charlesworth (ed.) (1954): The Cambridge Ancient History. Volume XI. The Imperial Peace A.D. 70-192. Cambridge.

Grane, Thomas (2007): The Roman Empire and Southern Scandinavia - a Northern Connection! University of Copenhagen. (Submittes as a PHD dissertation at the Saxo-Institute)

HALSAlL, Guy (2007): Barbarian Migrations and the Roman West, 376-568. New York.

Jones, GWyn (2001): A History of the Vikings. 2nd. ed. Oxford-New York.

JónAsson, BJöRN (2003): A Little Book about the Runes. Iceland.

Moberg, Vilhelm (1984): Népem története. Svédország a középkorban. Budapest.

Myhre, BJørn (2003): The Iron Age. In Knut Helle (ed.): The Cambridge History of Scandinavia. Vol I. Prehistory to 1520. Cambridge.

Pounds, Norman J.G. (2003): Európa történeti földrajza. Budapest, 2003. 
Sawyer, Birgit - Sawyer, Peter (2010): Medieval Scandinavia. From Conversion to Reformation circa 800-1500. Minnesota - London.

Sawyer, Peter Hayes (1982): Kings and Vikings. Scandinavia and Europe AD 700-1100. London-New York.

Stylegar, Frans-Arne (2013): Regionality in Iron Age Norway. A study of archeological cultures. In Khrapunov Igor - Stylegar, Frans-Arne (ed.): Inter Ambo Maria 2. Vest-Agder.
SzÁntó György Tibor (1997): Anglia története. Budapest.

SzéKely Melinda (2012): A germán népek kereskedelme és intézményei a Kr. u. 1. században. Belvedere Meridionale 23. évf. 3. sz. 25-35.

Yorke, BARBARA (2008): Kings and Kingdoms of the Early Anglo-Saxon England. London, 1992.

WiIK, Kalevi: Az európai népek eredete. Budapest, 2008.

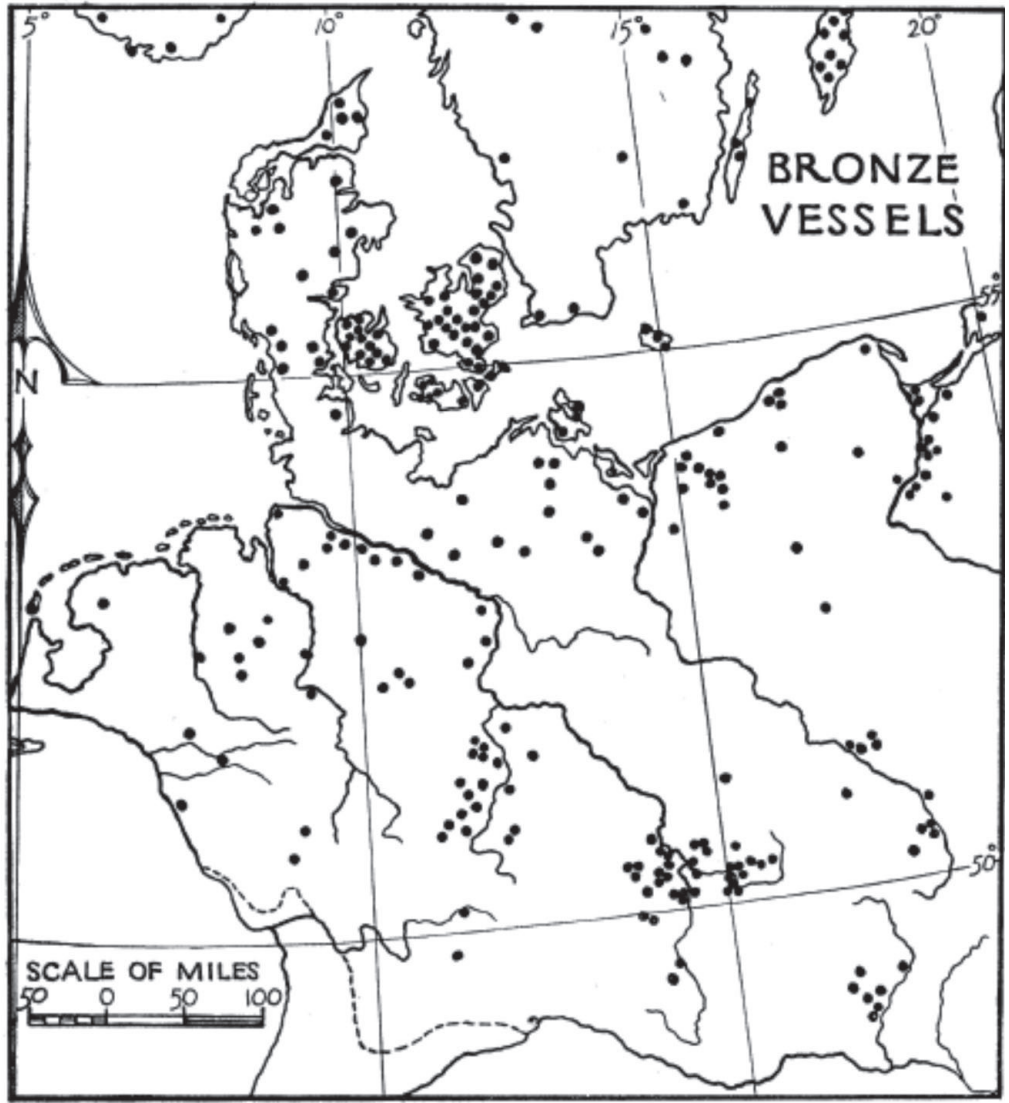

2. ÁBRA *Római eredetü bronz edények eloszlása. BROGAN, Olwen: Trade between the Roman Empire and the Free Germans. In: The Journal of Roman Studies 26/2. (1936), 195222, 208. 